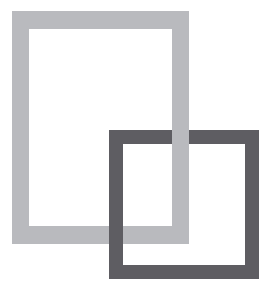

WARTOŚĆ ZABYTKOWA MIERZONA W METRACH. OCHRONA ZABYTKÓW W KONTEKŚCIE USTAWY 0 OCHRONIE ZABYTKÓW I OPIECE NAD ZABYTKAMI ORAZ PRAWA BUDOWLANEG0

Historic value measured in meters. Protection of monuments in the context of the Act on the Protection of Monuments and Protection of Monuments and the Construction Law

\title{
Helena Jadwiszczok-Molencka*
}

SUMMARY: This article explores the relations between the provisions of the Act on the Protection and Guardianship of Monuments and Sites and the Construction Law from the perspective of modern historic preservation. Particular emphasis is placed on the forms of direct historic preservation in the context of the record of historic monuments and sites, which, in spite of being mentioned in the said Act, is not referred to as a form of 'preservation'. What is also highlighted in this article is the necessity to make amendments to legal acts pertaining to classification and categorisation of historic monuments and sites. The author of this article is of the opinion that this can be achieved only by standardizing administrative regulations and deleting contradictory regulations from legal acts.

KEY WORDS: historic preservation, investment process, record of historic monuments and sites.

Niniejszy tekst ma na celu analizę korelacji Ustawy o ochronie zabytków i opiece nad zabytkami ${ }^{1}$ oraz Prawa budowlanego ${ }^{2}$ w kontekście faktycznej ochrony zabytków nieruchomych w Polsce. W ramy tychże rozważań włączony zostanie problem przemiany współczesnej przestrzeni urbanistycznej poprzez termomodernizację architektury, czyli montowanie na elewacji ingerujących w jej bryłę płyt styropianowych lub wełny mineralnej o grubości od kilku do nawet kilkunastu centymetrów zakotwiczanych za pomocą metalowych kołków zasłaniających oryginalny materiał budowlany. W ocenie konserwatorskiej przekształcenia te zacierają bowiem autentyzm, a postępująca degradacja z powodu zużycia technicznego wraz ze zliberalizowanym Prawem budowlanym staje się wymówką dla odejścia od pierwotnej formy uzależnionej czynnikami historycznymi, kulturą budowlaną danego okresu, estetyką architektoniczną

\section{Ochrona prawna architektury i urbanistyki}

Architektura, a więc budownictwo powstałe w określonym czasie, posiadające specyficzne dla

* Helena Jadwiszczok-Molencka, University of Silesia, Office of the Municipal Conservator of Monuments in Bytom

1 Ustawa o ochronie zabytków i opiece nad zabytkami, (Dz. U. 2014 poz. 1446, tekst jednolity z 10 września 2014), http://isap.sejm.gov.pl/DetailsServlet?id=WDU20140001446, dostęp [19.04.2016 r.]

2 Prawo budowlane (Dz. U. 1994 nr 89 poz. 414, ustawa z dnia 07 lipca 1994 r.), http://isap.sejm.gov.pl/ DetailsServlet?id=WDU19940890414. dostęp [19.05. 2016 r.]

3 Olenderek Joanna, Gentryfikacja czyli degeneracja łódzkich dóbr kultury wspótczesnej z lat 60. XX w. [w:] Modernizm w Europie. Architektura XX wieku do lat sześćdziesiątych i jej ochrona w Gdyni i w Europie, red. M. J. Sołtysik, R. Hirsch, Urząd Miasta Gdyni, Gdynia, 2014, s. 148. 
danego stylu architektonicznego cechy, a tym samym wysokość, detale, formę, chroniona jest prawnie poprzez określone ustawy jednakowe dla całego kraju związane tak z funkcją wydziałów architektury, jak i konserwatorów zabytków w urzędach.

Zgodnie $\mathrm{z}$ art. 7 Ustawy o ochronie zabytków i opiece nad zabytkami istnieje kilka form ochrony zabytków: wpis do rejestru zabytków (budynku, kwartału, układu urbanistycznego), uznanie za pomnik historii, utworzenie parku kulturowego, ustalenia ochrony w miejscowym planie zagospodarowania przestrzennego ${ }^{4}$.

W art. 3 tejże ustawy określono także znaczenie samego terminu „zabytek”, które będzie niezwykle istotne w ramach dalszych rozważań: zabytek - nieruchomość lub rzecz ruchoma, ich części lub zespoły, będące dziełem człowieka lub związane z jego działalnością i stanowiące świadectwo minionej epoki bądź zdarzenia, których zachowanie leży w interesie społecznym ze względu na posiadaną wartość historyczną, artystyczną lub naukową.

I tak wpis do rejestru zabytków zakłada ochronę konserwatorską niemal w stopniu całkowitym, gdyż projekt budowlany musi zyskać akceptację konserwatorską (na stopniu miejskim lub wojewódzkim w zależności od podpisanych porozumień), a na wszelkie prace musi zostać wydane pozwolenie. W przypadku układów urbanistycznych ochrona ta dotyczy nawet budynków współczesnych usytuowanych na wskazanym terenie. Dlatego też $\mathrm{w}$ przestrzeń nie są wprowadzane szkodliwe przekształcenia, a na wszelkie roboty remontowe i modernizacyjne ( $w$ tym też termomodernizacyjne) musi każdorazowo, przed pozwoleniem budowlanym, wydane zostać pozwolenie konserwatorskie ${ }^{5}$. Jednocześnie, w przypadku prowadzenia prac niezgodnie z pozwoleniem lub bez niego, istnieje konieczność wstrzymania przez konserwatora prac, a następnie wydania decyzji o przywrócenia zabytku do stanu pierwotnego ${ }^{6}$.

Także pomnik historii i park kulturowy stanowią formy ochrony dające możliwość decyzyjności właściwym organom na każdym szczeblu postępowania administracyjnego.

Ustalenia $\mathrm{w}$ miejscowym planie zagospodarowania przestrzennego stanowią natomiast analizę warstwy historycznej i współczesnej na danym obszarze w kontekście możliwych przemian i modernizacji. Plany te przyjmowane mogą być dla miast, dzielnic, kwartałów, ulic, czy nawet ich części. W powyższych aktach gmina lub inny samorząd określa działania, które mogą być wykonywane na przedmiotowym terenie. Należą do nich m.in. linia zabudowy, wysokość budynków, zabudowa jedno - i wielorodzinna, przemysłowa, produkcyjna, tereny zielone, montaż reklam, chronione wartości obiektów zabytkowych. I choć istnieje możliwość zapisu w planie zakazu działań budowlanych polegających na termomodernizacji, w rzeczywistości w niewielu przypadkach jest to wykorzystywane.

Paradoksalnie jednak Ustawa o ochronie zabytków i opiece nad zabytkami zawiera jeszcze jeden zapis dotyczący ochrony zabytków, niewymieniony jednak jako jedna $\mathrm{z}$ form ochrony w art. 7

4 Art. 7 Ustawy o ochronie zabytków..., http://isap.sejm.gov.pl/DetailsServlet?id=WDU20140001446, dostęp [19.04.2016 r.]

5 Art. 36 Ustawy o ochronie zabytków..., http://isap.sejm.gov.pl/DetailsServlet?id=WDU20140001446, dostęp [19.04.2016 r.]

6 Art. 43 i 45 Ustawy o ochronie zabytków..., http://isap.sejm.gov.pl/DetailsServlet?id=WDU20140001446, dostęp [19.04.2016 r.] 
ustawy. Zapisem takim jest ewidencja zabytków. I choć w swojej nomenklaturze zawiera wartościujący dopisek zabytek, odnoszący się do art. 3 ustawy, jak wskazane zostanie w toku dalszych rozważań, jest to bardzo ograniczona forma ochrony, dla której zachowanie nieruchomości w formie oryginalnej ze względu na posiadaną wartość często nie będzie leżało w interesie społecznym.

Ewidencja zabytków jako zapis pojawia się jednocześnie niezwykle często w Ustawie o ochronie zabytków. W art. 19 pkt. wskazuje się na konieczność jej uwzględniania przy tworzeniu wspomnianych miejscowych planów zagospodarowania przestrzennego, studium uwarunkowań, decyzji o ustaleniu lokalizacji inwestycji celu publicznego, czy też warunków sytuowania obiektów małej architektury, tablic, urządzeń reklamowych, ogrodzeń7. Jednocześnie zgodnie z art. 21 ewidencja zabytków jest podstawą do sporządzania programów opieki nad zabytkami przez województwa, powiaty i gminy ${ }^{8}$. $\mathrm{W}$ art. 22 pkt. 5 tłumaczy się natomiast, że we wskazanym zbiorze winny zostać ujęte: zabytki nieruchome wpisane do rejestru, inne zabytki nieruchome znajdujące się w wojewódzkiej ewidencji zabytków oraz pozostałe zabytki nieruchome wyznaczone przez wójta (burmistrza, prezydenta miasta) w porozumieniu $\mathrm{z}$ wojewódzkim konserwatorem zabytków. Jako inne zabytki nieruchome należy rozumieć formy, które posiadają wartość historyczną, artystyczną, naukową, jednakże nie zostały wpisane do rejestru zabytków. Ponadto, w tym samym artykule wskazuje się, iż nie jest to jedynie wykaz zawierający adres, datę powstania i styl architektoniczny, a każdy z wyróżnionych obiektów winien mieć założoną kartę ewidencyjną zawierającą także bieżący stan nieruchomości obrazowany przez dołączoną do niego fotografię.

Wskazać należy, iż Generalny Konserwator Zabytków prowadzi krajową ewidencję zabytków w formie zbioru kart ewidencyjnych znajdujących się w wojewódzkich ewidencjach zabytków, a wojewódzki konserwator zabytków administruje wojewódzką ewidencją zabytków w formie kart ewidencyjnych znajdujących się na terenie województwa. Wójt, burmistrz, prezydent miasta prowadzą natomiast gminną ewidencję zabytków w formie zbioru kart adresowych zabytków nieruchomych z terenu gminy.

Wojewódzka i gminna ewidencja zabytków winna wypełniać więc lukę w ochronie zabytków i obejmować obiekty, które nie są wpisane indywidualnie do rejestru i nie są usytuowane na układzie urbanistycznym wpisanym do rejestru lub też w miejscowym planie zagospodarowania przestrzennego w przypadku jego nieuchwalenia przez gminę. W rezultacie jednak ustawodawca nie sprecyzował właściwie jakie wartości są chronione. Jak zostanie bowiem wskazane, w myśl wspomnianego zliberalizowanego prawa budowlanego ${ }^{9} \mathrm{w}$ przypadku obiektów ujętych w ewidencji, nie bierze się pod uwagę ich wartości dla dziedzictwa, a jedynie wysokość budynku od podstawy po kalenicę dachu.

Jak zostało wspomniane, w przypadku obiektów rejestrowych decyzja administracyjna na każdym kroku jest konsultowana z właściwym konserwatorem zabytków, a później z wydziałem architektury. Obiekty ewidencyjne natomiast, choć posiadają ustawowy dopisek zabytek, w niewielu przypadkach są uzgadniane z organami ochrony zabytków, a prace na nich nie wymagają często prowadzenia żadnego postępowania administracyjnego. Dlatego też od woli właściciela lub zarządcy

\footnotetext{
Art. 19 Ustawy o ochronie zabytków..., http://isap.sejm.gov.pl/DetailsServlet?id=WDU20140001446, dostęp [19.04.2016 r.]

8 Art. 21 Ustawy o ochronie zabytków..., http://isap.sejm.gov.pl/DetailsServlet?id=WDU20140001446, dostęp [19.04.2016 r.]

9 Prawo budowlane..., http://isap.sejm.gov.pl/DetailsServlet?id=WDU19940890414, dostęp [19.05. 2016 r.]
} 
w dużej mierze zależy kształtowanie harmonii architektonicznej i urbanistycznej miast, zwłaszcza jeśli brać pod uwagę termomodernizację, jej zmianę kubatury, proporcji i kolorystyki budynków.

Pozwolenia na budowę, a więc też wykonanie projektu budowlanego przez architekta o uprawnieniach w przypadku docieplenia, zgodnie Z art. 29 Prawa budowlanego ${ }^{10}$, wymagają prace na budynkach, których wysokość wynosi powyżej $25 \mathrm{~m}$, w przypadku budynków mieszczących się pomiędzy $12 \mathrm{~m}$, a $25 \mathrm{~m}$, zgodnie $\mathrm{z}$ art. 30 Prawa budowlanego ${ }^{11}$, inwestor winien jedynie zgłosić zamiar wykonania prac, natomiast na budynkach poniżej $12 \mathrm{~m}$, zgodnie z art. 31 Prawa budowlanego ${ }^{12}$ prace termomodernizacyjne wykonywane są bez jakichkolwiek uzgodnień, co oznacza, że grubość warstwy izolacyjnej, technologia wykonania (w tym często zakrywanie dekoracji architektonicznej) oraz kolorystyka zależą wyłącznie od decyzji niewyspecjalizowanego w zakresie architektury inwestora.

Co za tym idzie, zakładając, że budynek został umieszczony w ewidencji zabytków, a jego wysokość to więcej niż $25 \mathrm{~m}$, właściwy wydział architektury przysyła projekt do uzgodnienia konserwatorowi zabytków, który wydaje postanowienie w tej sprawie. Jeśli zachodzi drugi przypadek, czyli inwestor zgłasza chęć wykonania prac, wydział architektury nie jest zobowiązany chronić obiektów, nawet jeśli są one w ewidencji. W trzecim przypadku natomiast cała procedura odbywa się poza urzędem. Rozbiórka obiektu ewidencyjnego zgodnie z art. 39 Prawa budowlanego ${ }^{13}$ wymaga już jednak uzgodnienia wojewódzkiego konserwatora zabytków.

Jedyną możliwością ingerencji konserwatorskiej w przypadkach wskazanych wyżej remontów, wykonywania prac budowlanych, w tym termomodernizacji w obiektach ewidencyjnych, jest wystąpienie wyprzedzająco do konserwatora zabytków o nieobligatoryjne zalecenia, w których wypowiada się on w zakresie planowanych prac na obiekcie uwzględniając jego wartości zabytkowe, historyczne, zapisy planu miejscowego, ogólne zasady estetyki. Paradoksalnie, z uwagi na fakt, iż zalecenia te mają charakter zwykłego pisma, inwestor nie jest zobowiązany się do nich dostosować.

\section{Czy zabytek ztermomodernizowany jest dalej zabytkiem?}

Jak zostało już wskazane, termomodernizacja jest procesem inwazyjnym wpływającym na architekturę i urbanistykę. Uważana jest ona także za remedium dla spękań tynków i wszelkich problemów wilgociowych budynku. Technologia zakłada mocowanie styropianu lub wełny za pomocą długich kołków wbijanych w elewację, następnie tynkowanie i malowanie.

a) Elewacje - w wyniku tego procesu zakrywane są ceglane i tynkowane dekoracje, których w styropianie odtworzyć nie można, a budynek staje się graniastosłupem pomalowanym atektonicznie $\mathrm{w}$ różnych niezgodnych $\mathrm{z}$ ochroną konserwatorską kolorach. Oryginalne tynki są niszczone wspomnianymi kołkami, w związku z czym proces jest niemożliwy

10 Art. 29 Prawa budowlanego..., http://isap.sejm.gov.pl/DetailsServlet?id=WDU19940890414, dostęp [19.05.2016 r.]

11 Art. 30 Prawa budowlanego..., http://isap.sejm.gov.pl/DetailsServlet?id=WDU19940890414, dostęp [19.05.2016 r.]

12 Art. 31 Prawa budowlanego..., http://isap.sejm.gov.pl/DetailsServlet?id=WDU19940890414, dostęp [19.05.2016 r.]

13 Art. 39 Prawa budowlanego..., http://isap.sejm.gov.pl/DetailsServlet?id=WDU19940890414, dostęp [19.05.2016 r.] 
do odwrócenia. Dołożenie dodatkowej warstwy sprawia także, że wnęki okienne stają się znacznie dłuższe, „basztowe”, doprowadzając do wnętrza mniej światła. Ponadto problemem wciąż jest rozwiązanie cokołu, który albo pozostaje w ogóle niedocieplony, gruba warstwa styropianu ociężale zwisa nad chodnikiem, a cokół ukryty jest w cieniu z tyłu (czasem pokrywa się go nieestetycznymi kamyczkami lamperiowymi lub cegłą klinkierową nieodpowiadającą stylowi architektonicznemu budynku). Drugim punktem styku jest dach, gdzie także gzyms zostaje zupełnie wyeliminowany, gdyż odtworzony wystawałby poza połać.

b) Detale - modernizm choć rezygnował $\mathrm{z}$ upiększeń historyzujących wprowadzał często wertykalne i horyzontalne podziały tynku, a drobna zgeometryzowana dekoracja mogła pojawiać się w płycinach i portalach. Natomiast elewacje zdobiły wyszukane maszty. Styl ten cechował się także zaokrągleniami bryły i wydatnymi gzymsami uskokowymi. Każdy z powyższych elementów w termomodernizowanych budynkach zostaje usunięty, gdyż koszt jego odtworzenia byłby niezmiernie wysoki. Dlatego też gzymsy zostają niemal całkowicie zniwelowane i topią się w nowym układzie. Inna możliwość zakłada ich odtworzenie wstyropianie, jednakże proporcje nie odpowiadają oryginalnym i budynek traci swój charakter. Maszty zdejmowane przed pracami nie są montowane po ich skończeniu, gdyż są za ciężkie, by umieścić je na tak nietrwałym materiale jak styropian. Nie odtwarza się także drobnych podziałów, gdyż koszt byłby za duży. Znacznej dewastacji ulega zwłaszcza strefa wejścia. Ozdobny portal zostaje w całości przykryty styropianem, detale - okładziny, półkolumny, pilastry, bonia, rustyka nie są odtwarzane, a na ich miejscu pozostawia się tylko pomalowany materiał. Co również wpływa niekorzystnie na architekturę, strefę wejścia pokrywa się klinkierem lub lamperią z kamyczków.

c) Punkty styku - termomodernizacja jest zwłaszcza widoczna w ciągach zabudowy, powszechnie występujących jako tanie budownictwo funkcjonalistyczne. Zespół pięciu budynków tworzących pierwotnie jeden korpus flankowany przez ulicę oraz zieleń, urozmaicony był przez ozdobne portale, mieniące się tynki z domieszkami kruszyw oraz otworowania okienne. Czytelny był układ połączonych budynków, jak i cała kompozycja urbanistyczna. Termomodernizacja wykonywana przez wspólnoty mieszkaniowe realizowana jest $\mathrm{w}$ większości przypadków indywidualnie dla każdego budynku. W związku z czym we wspomnianym ciągu każdy obiekt pokrywany jest warstwą styropianu o innej grubości, w inny sposób rozwiązywane są detale architektoniczne, cokól, widoczne jest zwłaszcza łączenie, gdyż inwestorzy dbają, by nie wchodzić na cudzą własność. Najgorszym dla budownictwa wydaje się jednak malowanie budynków w ciągu na różne kolory. Jednolitość, które cechowała funkcjonalizm zamieniona zostaje w tęczowe pasy różne dla wnęk okiennych, kondygnacji, osi. Projektanci nie przejmują się stopniem dopasowania nowej kolorystyki do pierwotnego wzorca, gdyż szarość zastąpiona ma być przez kolor, który „wszystko ożywi”.

d) Technologia - powszechnie uważa się, że styropian lub wełna wpływają korzystnie na walory cieplnebudynku.Wrzeczywistościjednakcałkowiteuszczelnienieobiektuarchitektonicznego tworzy z niego termos, w którym wilgoćnie ma ujścia i w rezultacie skutkuje to zawilgoceniami, powstawaniem grzybów i pleśni na ścianach. Mikrowentylacja stolarki okiennej w przeciwieństwie do okien PCV zapewniała trwały nawiew, w związku z czym wskazane 
wyżej problemy nie występowały. Ponadto cegła, jako materiał szybko nagrzewający się i dobrze trzymający ciepło, obłożona styropianem zupełnie traci swoją funkcję i zawilgaca się. Należy także zauważyć, że styropian jest materiałem słabej jakości, który jest łatwo uszkodzić, a pożar go topi. Uszkodzenia natomiast są niemożliwe do naprawy. Dodatkowo zwrot części kosztów za przeprowadzone prace motywują wspólnoty mieszkaniowe do zaciągania kredytów i wykonywania prac termomodernizacyjnych. W rzeczywistości jednak nikt nie wspomina, że ów poniesiony koszt nie zostanie nigdy zwrócony z naddatków ogrzewania, a styropian jako materiał nietrwały może nie wytrzymać próby czasu.

Współcześnie architektura w całej Polsce bezrefleksyjnie pokrywana jest warstwami styropianu, na który nakłada się cienkoziarnisty tynk tworząc atektoniczne, sztuczne graniastosłupy ułożone nierówno w stosunku do linii zabudowy. Kolory: różowe, zielone, niebieskie, żółte, czerwone ułożone pasowo łączą się z estetyką kiczu i wyraźnie polemizują z architekturą otoczenia, pierwotnie zakomponowaną tak, by wszystkie czynniki były równouprawnione, bądź by stanowić tło dla realizacji prymarnej.Zmienia sięobiekt, wktórego elewację wkuto kilku-lub kilkunastocentymetrowy styropian i pomalowano $\mathrm{w}$ intensywnej kolorystyce. Zmienia się przestrzeń, a więc wzajemne zależności budynków pomiędzy sobą. Swoista wolność wynikająca z obowiązującego prawa, jak i społecznej potrzeby odróżniania się jest tu pojęciem negatywnym, związanym z odtwórczym dążeniem do indywidualizmu, oderwaniem się od tradycji, afirmacją oryginalności ${ }^{14}$.

Wskazując na fakt, że o wartości architektury stanowi przede wszystkim jej oryginalna substancja zabytkowa, niezalecane jest zwłaszcza stosowanie technologii, która stworzona została do innych zadań remontowych. Dlatego też termomodernizacja jako proces obcy, szkodliwy, nie jest zalecana. Zwłaszcza, że np. zabudowa z okresu 20-lecia międzywojennego to architektura, której grubość murów wynosiła 0,5 metra. Dlatego też wykonywane w tego typu budynkach bilanse energetyczne w takiej technologii, jak w budynkach współczesnych są niemiarodajne i zniekształcają właściwe potrzeby ${ }^{15}$.

Ustawa o ochronie zabytków i opiece nad zabytkami w art. 4 wskazuje, że: Ochrona zabytków polega, w szczególności, na podejmowaniu przez organy administracji publicznej działań mających na celu: zapewnienie warunków prawnych, organizacyjnych i finansowych umożliwiających trwałe zachowanie zabytków oraz ich zagospodarowanie i utrzymanie, zapobieganie zagrożeniom mogącym spowodować uszczerbek dla wartości zabytków, udaremnianie niszczenia i niewłaściwego korzystania z zabytków, przeciwdziałanie kradzieży, zaginięciu lub nielegalnemu wywozowi zabytków za granicę, kontrolę stanu zachowania i przeznaczenia zabytków, uwzględnianie zadań ochronnych $\mathrm{w}$ planowaniu i zagospodarowaniu przestrzennym oraz przy kształtowaniu środowiska. W art. 5 zapisano natomiast, że: Opieka nad zabytkiem sprawowana przez jego właściciela lub posiadacza polega, w szczególności, na zapewnieniu warunków: naukowego badania i dokumentowania zabytku, prowadzenia prac konserwatorskich, restauratorskich i robót budowlanych przy zabytku, zabezpieczenia i utrzymania zabytku oraz jego otoczenia w jak najlepszym stanie, korzystania z zabytku w sposób zapewniający trwałe zachowanie jego wartości,

14 Bonenberg Wojciech, Współczesny wymiar nowoczesności w architekturze [w:] Nowoczesność w architekturze. Warsztaty projektowe: Bytom - architektura pustych miejsc, Politechnika Śląska. Wydział Architektury, Gliwice 2007, s. 28, 29.

15 Jagiellak Anna, Jak „modernizować” modernizm, Urząd Miejski w Warszawie, Warszawa 2014, s. 31-32. 
popularyzowania i upowszechniania wiedzy o zabytku oraz jego znaczeniu dla historii i kultury.

Jednakże korelacja Ustawy o ochronie zabytków i Prawa budowlanego skutecznie zaburza te zapisy, gdyż organy administracji publicznej nie są w stanie skutecznie chronić pojedynczych obiektów architektonicznych, czy też zespołów zabudowy. Niemożliwym jest także trwałe zachowanie obiektów, których forma uległa całkowitej przemianie w wyniku prac „modernizacyjnych”, gdyż obiekt taki utracił swoje cechy stylowe stając się współczesną, graniastosłupową hybrydą o intensywnej atektonicznej kolorystyce. Zapisy przeznaczone dla posiadaczy zabytku interpretowane mogą być natomiast niejednoznacznie. Bowiem, czyż utrzymanie zabytku w jak najlepszym stanie nie może być interpretowane jako przeprowadzanie na nim prac remontowych w nowoczesnej technologii, za które dziś uchodzi termomodernizacja?

Często w przypadku wykonywania aktualizacji ewidencji zabytków, konserwator staje przed problemem, czy obiekty ztermomodernizowane dalej winny znajdować się w wykazie, czy też należy je z niego usunąć. Z jednej strony stanowią one wytwór danej epoki i nadal znajdują się w przestrzeni. $\mathrm{Z}$ drugiej zaś strony zatraciły swoją formę i wszelkie cechy, które świadczyłyby o ich proweniencji. Na podstawie samych aspektów wizualnych uchodzić mogę one za tanie budownictwo współczesne.

W poprawnym rozumieniu art. 5 Ustawy o ochronie zabytków przed rozpoczęciem prac na budynku zadaniem inwestora nie jest jednak dopasowanie posiadanego budynku do technologii, jak nagminnie jest to realizowane. Kluczowym w pierwszej fazie będzie rozpoznanie obiektu polegające na stwierdzeniu stanu technicznego (np. czy występuje zawilgocenie, czy są spękania, czy na elewacjach występują luźne tynki). Następnie po wylistowaniu wszystkich zauważonych prac na obiekcie z uwzględnieniem stopnia dewastacji wszystkich elementów jest opracowanie programu prac naprawczych każdorazowo indywidualnie dopasowanych do obiektu. Istotną kwestią jest zwłaszcza badanie oryginalnej substancji zabytkowej i jej zachowanie przy wykorzystaniu prac renowacyjnych, ewentualnie rekonstrukcyjnych. Badania takie ułatwione są zwłaszcza w przypadku możliwości skorzystania z planów archiwalnych budynku zawierających opisy technologiczne, rysunki wszystkich kondygnacji, szczegółowe szkice elewacji, a także dopisywane w dalszych częściach remonty i modernizacje. Poprzez tego typu działania możliwym jest m.in. ustalenie pierwotnego wystroju i kolorystyki elewacji i wnętrz ${ }^{16}$. Należy także wskazać, że istotnym elementem jest dziedzictwo niematerialne obiektu, jego historia ${ }^{17}$.

\section{Jak ratować budynki ewidencyjne?}

Jak zostało wskazane, ewidencja zabytków jest sztucznym tworem, który nie zapewnia prawie żadnej ochrony, zwłaszcza biorąc pod uwagę fakt, iż większość architektury modernistycznej i historyzującej poddawanej pracom termomodernizacyjnym mieści się w przedziale pomiędzy 20, a 25 m wysokości, w związku z czym konserwator zabytków (miejski lub wojewódzki) nie ma możliwości ingerowania w planowane prace.

Wydaje się więc, że należałoby ująć wspomnianą architekturę w wyższą formę ochrony. Jednakże wpisanie indywidualnie lub jako układów urbanistycznych do rejestru zabytków wszystkich

16 Jagiellak Anna, Jak „modernizować”..., s. 30-31.

17 W Bytomiu, jak i innych miastach występują obiekty, na których widoczne są uszkodzenia niewielkich rozmiarów. Nie są to jednak zniszczenia wynikłe z eksploatacji, a dziury po ostrzelaniach powstałe w 1945 r., które zakryte wtórną warstwą tynku, styropianu lub wełną stanowić będą o zafałszowywaniu historii miasta. 
wartościowych obiektów jest zadaniem nie do zrealizowania. Po pierwsze sam proces trwałby niezmiernie długo, a ustawodawca nie przewidział, by po wszczęciu postępowania o wpis wprowadzić tymczasową formę ochrony dającą konserwatorowi możliwość wypowiedzenia się podczas planów inwestycyjnych. Dlatego też w trakcie wpisywania do rejestru zabytków mogłoby się okazać, że formy, które konserwator chciał chronić zostały już ztermomodernizowane, więc wpis nie ma racji bytu, chyba że po wpisie nakazałby on przywrócenie zabytku do stanu pierwotnego, co z kolei znacznie wydłużyłoby procedurę i naraziło inwestora na duże koszta. Po drugie w przestrzeniach urbanistycznych o jednolitej zabudowie funkcjonalistycznej, gdzie większa część architektury została już przekształcona nie byłoby podstaw odmówienia pozostałym właścicielom przeprowadzenia analogicznych prac, skoro te pierwsze zostały wykonane zgodnie z prawem.

Właściwą wydaje się edukacja zarządców i mieszkańców, dla których poprawa estetyki budynku łączy się z jego obłożeniem styropianem i pomalowaniem na kilka kolorów. Nie mają oni świadomości wartości architektury, w której mieszkają i za wszelką cenę upodabniają ją do kubicznej współczesnej zabudowy. Ponadto wybierają oni najczęściej najtańszą ofertę biur projektowych, które wprowadzają owe atektoniczne kolorowe podziały. Należy także dodać, iż nawet w sytuacji, gdy zarządca jest świadomy, iż przyczynia się do niszczenia formy zabytkowej, zatrudniająca go wspólnota mieszkaniowa może z nim rozwiązać umowę, jeśli nie zrealizuje planowanych przez nią prac.

Edukacja nie powinna się jednak ograniczać tylko do wskazanych wyżej, ale obejmować także dzieci w jak najmłodszym wieku, by termin dziedzictwa kulturowego oraz zabytku stanowił jednoznacznie interpretowalną wartość. Co oczywiste jednak, najistotniejszą wydaje się być jednak zmiana prawa o ochronie zabytków i prawa budowlanego, które w jednoznaczny sposób uporządkowałaby terminologię, sposoby ochrony konserwatorskiej umożliwiając służbom w większym stopniu wpływanie na przekształconą przestrzeń miejską. Przede wszystkim bowiem wprowadzając ochronę poprzez ewidencję zabytków łączyć powinno się to z rzeczywistym wpływem na wskazane obiekty, a nie tylko listowym ich wyróżnieniem i pozostawieniem wykonywania na nich wszelkich działań bez żadnych uzgodnień. Wystarczy nadmienić, że trzykondygnacyjna zabudowa funkcjonalistyczna liczy najczęściej $11 \mathrm{~m}$ wysokości, więc właściciele nie muszą nawet zgłaszać w urzędzie wykonywanych prac. Prowadzi to do opisanej sytuacji, gdy w jednym ciągu zabudowy każdy budynek jest inny.

Istotna jest również wiedza jak modernizować, by wykonywane prace rzeczywiście poprawiały walory cieplne i jednocześnie odpowiadały oryginalnej wizji architektonicznej.

W przypadku zaś wykonywania prac remontowych winno się pozostawić, jeśli to możliwe jak największe powierzchnie oryginalnego tynku, przy wprowadzeniu nowego, kolorystykę należy ustalić na podstawie badań stratygraficznych, można wymienić i ocieplić pokrycie dachowe, nie zmieniając jednocześnie jego kształtu ${ }^{18}$. Renowacji wymaga także wnętrze. Jednakże w wyniku zmian procesów technologicznych, wykonanie dziś powszechnie występujących kiedyś lastryko, tynków wielowarstwowych, stało się zadaniem nie do zrealizowania. Paradoksalnie procesy, które uważane były w modernizmie za najtańsze, jak wspomniane wyżej, dziś są niezwykle kosztowne, gdyż zaledwie kilka firm potrafi je wykonywać w sposób prawidłowy. Skutkuje to tym, że inwestorzy decydują się na

18 Urbanik Jadwiga, Renowacja wzorcowego osiedla Werkbundu we Wrocławiu - sukcesy i porażki [w:] Nowoczesność w architekturze..., s. 213. 
tańsze płytki wewnątrz oraz styropian na elewacji ${ }^{19}$.

Dodatkowym problemem jest także sama definicja zabytku jako indywidualnej formy, jak i zespołu zabudowy, gdyż zakres ochrony wraz z upływem lat wydaje się wciąż sztucznie rozszerzać (im coś starsze tym bardziej zabytkowe). Mianem zabytkowego określa się często obiekty zrealizowane coraz bliżej współczesności, jednakże mimo uznania ich wartości, nie są one chronione w rozumieniu konserwatorskim $^{20}$. Nie jest możliwa także ich historyczna analiza, pozbawiona postsocjalistycznej emocji. Dodatkowo brak wiedzy oraz przyjętych kryteriów sprawia, że architktura tego typu nie jest postrzegana jako zabytkowa. Poza tym, zważywszy na fakt, iż ich architekci są dalej czynni twórczonasuwasięproblem dychotomiiwspółczesnościihistorii ${ }^{21}$.Jakukazująjednakprowadzonewtym kierunkubadaniatakarchitekturasocjalistyczna,jakipóźnomodernistycznaniemożebyćrozpatrywana w oderwaniu od sztuk plastycznych - malarstwa i rzeźby. Często już na etapie projektowania architekt rozpatrywał jaki kolor i rytm w zakresie elewacji winien zastosować, by zaprojektowany obiekt stanowił nawiązanie do historycznej przestrzeni, jaki odznaczał się swoją nowoczesną formą ${ }^{22}$. I choć w zespołach zabudowy mieszkaniowej lat 50. - 70. XX w. wydawać się może, że doszło do odejścia od dawnego budownictwa, zabudowę taką należy rozpatrywać także jako układ urbanistyczny, gdzie elewacja jest elementem zdeprecjonowanym na rzecz stosunków architektury względem siebie ${ }^{23}$, bo choć budynek stał się wówczas jednostką zastąpioną masowym produktem, współistniał on z całym systemem infrastruktury zrealizowanym w oderwaniu od trzonu miast jako nowoczesne osiedla mieszkaniowe o zupełnie innym standardzie życia ${ }^{24}$.

\section{Podsumowanie}

Prawo stanowiące o ochronie zabytków powinno na terenie każdego kraju mieć wartość prymarną, gdyż stanowi o tożsamości tego, co identyfikuje tak cały kraj, jak i pojedyncze miasto, czy wieś. W swej ogólności winno ono zawierać zapisy, które w sposób jednoznaczny dałyby sięinterpretować i stosować, wprowadzając jednocześnie przejrzysty proces administracyjny dla konserwatorów, wydziałów architektury, inspektorów nadzoru budowlanego i posiadaczy nieruchomości.

Współcześnie jednak poprzez sztuczne twory ustawowe, jak wspomniana ewidencja zabytków, nie ma możliwości ochrony tego, co ustawodawca określił jako zabytek. Zachęca się wręcz, poprzez zapisy prawa budowlanego, do całkowitego, przekształcania oryginalnej formy architektonicznej oraz struktury urbanistycznej. Dziś bowiem dziedzictwo materialne w dziedzinie budownictwa nie wyraża się poprzez styl architektoniczny, architekta, kunszt wykonania. Jak bezsprzecznie wykazano powyżej, obecnie zabytki liczone są w metrach, a ich ochrona zaczyna się dopiero po przekroczeniu $25 \mathrm{~m}$.

19 Lewicki Jakub (2014), Badania, definicje, wartościowanie a rzeczywistość, czyli dlaczego utracono czołowe dzieła polskiego modernizmu [w:] Modernizm w Europie...., s. 150-154.

20 Tamże.

${ }_{21}$ Marciniak Piotr, Niewygodny zabytek czy zła architektura? O kryteriach i sposobach ochrony powojennego dziedzictwa modernizmu [w:] Modernizm w Europie..., s. 158-159.

22 Borowik Aneta, Architektura lat 60. XX wieku w Katowicach. Przykłady, twórcy, stan zachowania [w:] Modernizm w Europie.., s. 166.

23 Np. zabudowania Nowej Huty, Nowych Tychów.

24 Buriak Aleksandra, ZSRR 1955-1965. Industrialna urbanistyka z polityczna odwilża w tle [w:] Modernizm w Europie..., s. 94. 
Jakpokazująbadania, wciąż poszukuje sięarchitektury,która sprostałabynaszemubiologicznemu, zmysłowemu i motorycznemu byciu w świecie, a pasowałaby o wiele bardziej, niż ta racjonalistyczna. Dlatego też architektura winna być transhumanistyczna tworząc ścisłą relację z otoczeniem, przyrodą 25 . „Styropianizacja” nie jest odczytywana przez większą część społeczeństwa jako proces szkodliwy prowadzący do destrukcji architektury i zmiany jej charakteru. Wydaje się prawdopodobnym, że proces ten postrzegany jako pozytywna zmiana przestrzeni wynika z błędnego definiowania dziedzictwa kulturowego, a także postkomunistycznej potrzeby pokolorowania szarej przestrzeni, w której jeszcze kilka dekad temu wszystko było jednakowe. Działania wspólnot mieszkaniowych prowadzą natomiast do skrajnego odróżniania się budynków od siebie, nawet w ramach jednolitej zabudowy. Jeszcze niedawno pojawiały się koncepcje burzenia obiektów tradycyjnych, by na ich miejscu wstawiać zabudowę nową, jednakże polemika konserwatorska wprowadzając pojęcie zabytku wpłynęła korzystnie na rozróżnienie form tradycyjnych, nowoczesnych, współczesnych oraz modernizację, dzięki czemu w przypadku wielu obiektu doceniono ich indywidualny styl i historyczne ukorzenienie ${ }^{26}$.

Reasumując powyższe, istnieje dużym problem ochrony zabytków wynikający ze zmiany zakresu ochrony, nieskutecznego definiowania tego, co jest obiektem zabytkowym, dużej ilości mało skutecznych zapisów, nieprecyzyjne określenia w ustawach o ochronie zabytków i opiece nad zabytkami, prawie budowlanym. Do powyższych zaliczyć można również nieprecyzyjne wpisy do rejestru zabytków, poglądy danego konserwatora zabytków ${ }^{27}$, a także ukierunkowane lobby, jakim współcześnie jest termomodernizacja.

Dlatego też wybrzmiewającym w niniejszym artykule problemem jest przede wszystkim zagadnienie klasyfikacji i kategoryzacji zabytków. Jak wykazano, współczesna ochrona zabytków wyrażająca się poprzez przepisy prawa daje bardzo ograniczone możliwości rzeczywistej ochrony konserwatorskiej. Stosowana zaś w ustawie nomenklatura w stopniach ogólnym oraz szczegółowym nie są ze sobą tożsame, o czym świadczyć może termin zabytek w korelacji z formami ochrony, a przede wszystkim zaś z ewidencją zabytków stanowiącą w istocie nierespektowaną, zakamuflowaną $\mathrm{w}$ ustawie formę quasiochrony. W przypadku utrzymania ewidencji w ustawie $\mathrm{w}$ jej obecnej formie, zacząć należy od jej nazewnictwa. Termin ewidencja zabytków jest mylący i utożsamiany z przytaczanymi formami ochrony, do której w istocie ewidencja się nie zalicza. Problemem jest jednak fakt, iż ewidencja składa się z elementów ruchomych oraz nieruchomych, więc wprowadzenie np. terminologii ewidencja architektury nie wydaje się właściwym. Nie jest także ewidencją dziedzictwa, gdyż składa się z elementów materialnych, do dziedzictwa zaś zaliczylibyśmy także te niematerialne, jak np. gwara, czy też proces wytwarzania rzemiosła, które dziś nie są chronione wcale. Całkowita zaś rezygnacja w ustawie z ewidencji prowadziłaby zaś do przewartościowania formy ochrony wyrażającej się poprzez wpis do rejestru zabytków. Wpisać do niego należałoby tkankę architektoniczną, która choć posiadająca wartość dla dziedzictwa nie stanowi realizacji wybitnych. Tym samym rejestr zabytków przejąłby funkcję dzisiejszej ewidencji. Ponadto skutkowałoby to także subiektywizmem

${ }_{25}$ Cibis Jerzy (2007), Nowoczesność czy wspótczesna deformacja [w:] Nowoczesność w architekturze..., s. 54.

26 Barylewska-Szymańska Ewa, Szymański Wojciech, W stronę nowoczesności. Działalność Urzędu Budowlanego Wolnego miasta Gdańsk w latach 1927-1933 [w:] Modernizm w Europie..., s. 65.

27 Lewicki Jakub, Badania, definicje, wartościowanie a rzeczywistość, czyli dlaczego utracono czołowe dzieła polskiego modernizmu..., s. 150-156. 
klasyfikacji wyrażającym się poprzez dzielenie rejestru na dodatkowe klasy zabytków w zależności od ich formy, wartości historycznej itd.

Dlatego też właściwym wydaje się uznanie ewidencji za formę ochrony zabytków, do której zaliczyłoby się bezwzględnie wszystkie realizacje architektoniczne wartościowe jako obiekty indywidualne, czy też urbanistyczne zespoły zabudowy. $\mathrm{W}$ ich przypadku zaś nie wymagałoby się pozwolenia konserwatorskiego, jak ma to miejsce w budynkach rejestrowych, a postanowienia (uzgodnienia - tak do elewacji, jak i do wnętrz), co oznacza, że konserwator miałby możliwość każdorazowo wypowiadać się do prowadzonych $\operatorname{prac}^{28}$. Zmiana taka nastąpić może jednak tylko i wyłącznie po zmianie prawa budowlanego. Współczesna jego liberalizacja w korelacji z ustawą o ochronie zabytków i opiece nad zabytkami prowadzi bowiem do szybko postępującej dewastacji zwłaszcza modernistycznej tkanki architektonicznej. Pojęcie prace budowlane w ustawie zostało bardzo ograniczone i dziś niewiele uzgodnień w tych obiektach prowadzonych jest przy udziale służb konserwatorskich. Warto tutaj dodać, że np. wymiana oryginalnej stolarki okiennej oraz drzwiowej w obiektach nierejestrowych nie wymaga żadnych uzgodnień, gdyż w świetle prawa nie są to prace budowlane. Dlatego też wysokiej klasy zdobiona stolarka, indywidualna dla niemal każdego obiektu niszczona jest bezpowrotnie bez żadnej inwentaryzacji.

Parafrazując, w celu właściwej kategoryzacji i klasyfikacji zabytków podjąć należy dyskusję nad zmianą zarówno ustawy o ochronie zabytków i opiece nad zabytkami, jak i nad prawem budowlanym. Poprzez szczegółowe badania zachowanego jeszcze dziedzictwa podjąć należy się zdefiniowania tego, co należy bezwzględnie chronić w każdej z ustawowych form ochrony (np. elewacje, wnętrza, stolarkę, wyposażenie). Następnie winno się jako prace budowlane określić wszelkie działania, które prowadzą do nawet najmniejszej zmiany formy architektonicznej. Co najistotniejsze, każdorazowo prace na zgłoszenie wbudynkach zabytkowych,jeślijakieśbędą takzaklasyfikowaneprzezwydziałyarchitektury, winny być przekazywane do zaopiniowania właściwym służbom konserwatorskim. Z uwagi zaś na daleko posuniętą degradację tkanek urbanistycznych koniecznym wydaje się przeprowadzenie badań oraz odtworzenie zniszczonych dziś elementów przy prowadzonych w przyszłości na tych budynkach pracach. To zaś łączyć winno się ze zmianą uprawnień służb konserwatorskich, które współcześnie mają niezwykle ograniczone możliwości w przypadku niszczenia tego, co ustawa określa jako zabytek.

W zakresie zaś opieki nad zabytkami, ustawowe zapisy wprowadzić powinny jednoznaczność, gdyż $\mathrm{w}$ świetle opisywanych $\mathrm{w}$ niniejszym tekście działań termomodernizacyjnych, także i one traktowane mogą być przez właścicieli lub posiadaczy zabytków za właściwe, wpływające korzystnie na architekturę. To z kolei prowadzi do przytaczanego już problemu edukacji właścicieli i zarządców nieruchomości, którzy nie mają obowiązku historycznego rozpoznania swoich obiektów, więc ich działania opierają się zwłaszcza na stosowaniu opisywanych już współczesnych technik budowlanych.

28 Współcześnie także wymaga się postanowienia konserwatorskiego, jednakże tylko w przypadku, gdy prowadzone prace wymagają pozwolenia na budowę, co znacznie ogranicza możliwość ochrony dziedzictwa. 


\section{Bibliografia:}

1. Barylewska-Szymańska Ewa, Szymański Wojciech, W strone nowoczesności. Działalność Urzędu Budowlanego Wolnego miasta Gdańsk w latach 1927-1933 [w:] Modernizm w Europie. Architektura XX wieku do lat sześćdziesiątych i jej ochrona w Gdyni i w Europie, red. M. J. Sołtysik, R. Hirsch, Urząd Miejski w Gdyni, Gdynia 2014.

2. Basista Andrzej, Architektura i wartości, Universitas, Kraków 2009.

3. Blake Peter, Mies van der Rohe: architektura i struktura, tłum. J. Puchalska, Wydawnictwa Artystyczne i Filmowe, Warszawa 1991.

4. Bonenberg Wojciech, Współczesny wymiar nowoczesności w architekturze [w:] Nowoczesność $w$ architekturze. Warsztaty projektowe: Bytom - architektura pustych miejsc, Politechnika Śląska. Wydział Architektury, Gliwice, 2007.

5. BorowikAneta,Architekturalat60.XXwiekuw Katowicach.Przykłady, twórcy, stanzachowania [w:] Modernizm w Europie. Architektura XX wieku do lat sześćdziesiątych i jej ochrona w Gdyni i w Europie, red. M.J. Sołtysik, R. Hirsch, Urząd Miejski w Gdyni, Gdynia 2014.

6. Buriak Aleksandra, ZSRR 1955-1965. Industrialna urbanistyka $z$ polityczna odwilża w tle [w:] Modernizm w Europie. Architektura XX wieku do lat sześćdziesiątych i jej ochrona w Gdyni i w Europie, red. M.J. Sołtysik, R. Hirsch, Urząd Miejski w Gdyni, Gdynia 2014.

7. Cibis Jerzy, Nowoczesność czy współczesna deformacja [w:] Nowoczesność w architekturze. Warsztaty projektowe: Bytom - architektura pustych miejsc, Politechnika Śląska. Wydział Architektury, Gliwice 2007.

8. Czajka Roman, Nowoczesna? Współczesna architketura mieszkaniowa, [w:] Nowoczesność $w$ architekturze. Warsztaty projektowe: Bytom - architektura pustych miejsc, Politechnika Śląska. Wydział Architektury, Gliwice 2007.

9. Czarnecki Władysław, Planowanie miast i osiedli, Państwowe Wydawnictwo Naukowe, Poznań 1965.

10. Bytom śródmieście z Rozbarkiem. Aktualizacja części konserwatorskiej studium urbanistycznohistorycznego z 1985 r., red. Danilczyk L., Kasprzyk M., Kraków 1998.

11. Denison Edward, Erytrea a kwestia modernizmu poza krajami Zachodu, [w:] Modernizm w Europie. Modernizm w Gdyni, Architektura XX wieku do lat sześćdziesiątych i jej ochrona w Gdyni i w Europie, Urząd Miejski w Gdyni, Gdynia 2014.

12. Dolistowska Małgorzta, Nowoczesna Polska na Kresach. Architektura użyteczności publicznej w latach 30. XX wieku na ziemiach pótnocno-wschodnich II Rzeczypospolitej [w:] Modernizm w Europie. Modernizm w Gdyni, Architektura XX wieku do lat sześćdziesiątych i jej ochrona w Gdyni i w Europie, Urząd Miejski w Gdyni, Gdynia 2014.

13. Drabina Jan, Historia Bytomia: od średniowiecza do współczesności 1123-2010, Towarzystwo Miłośników Bytomia, Bytom 2010.

14. Drabina Jan, Fleischer Maksymilian, Stare fotografie Bytomia z lat 1865-1922, Muzeum Górnośląskie w Bytomiu, Towarzystwo Miłośników Bytomia, Bytom 1995.

15. Bytom powojenny 1945-2002 we wspomnieniach i na fotografii, red. Drabina Jan, Muzeum Górnośląskie w Bytomiu, Bytom 2002.

16. Dzielnice Bytomia na starych fotografiach, pocztówkach i planach, red. Drabina Jan, Muzeum Górnośląskie w Bytomiu, Bytom 1998. 
17. Stary Bytom w dawnej fotografii/Das alte Beuthen auf fruher Fotografie, red. Drabina Jan, Holeksa K., Muzeum Górnośląskie w Bytomiu, Bytom 2004.

18. Droń Maciej, Zapomniany artysta, http://2012.zyciebytomskie.pl/artykul. php?id=1402\&glowny=0, [dostęp: 21.05.2016 r.]

19. Hałaś Marcin, Nadolski Przemysław, Walerjański Dariusz, Ślad przeszłości. Bytom wielokulturowy, Urząd Miejski w Bytomiu, Bytom 2004.

20. Haspel Jörg, Powojenne zabytki i miejsca pamięci Berlina. Wspólne dziedzictwo zimnej wojny podzielonej metropolii [w:] Modernizm w Europie. Architektura XX wiekudo latsześćdziesiątych i jej ochrona w Gdyni i w Europie, red. M.J. Sołtysik, R. Hirsch, Urząd Miejski w Gdyni, Gdynia 2014.

21. Hirsch Robert, Tynki elewacyjne w architekturze Modernistycznej Gdyni [w:] Modernizm w Europie. Architektura XX wieku do lat sześćdziesiątych i jej ochrona w Gdyni $i$ w Europie, red. M. J. Sołtysik, R. Hirsch, Urząd Miejski w Gdyni, Gdynia 2014.

22.Hoffmann Jeremie, Miasto nowoczesne na przykładzie Tel Awiwu [w:] Modernizm $w$ Europie. Architektura XX wieku do lat sześćdziesiątych i jej ochrona w Gdyni i w Europie, red. M. J. Sołtysik, R. Hirsch, Urząd Miejski w Gdyni, Gdynia 2014.

23. Jagiellak Anna, Jak „modernizować” modernizm, Urząd Miejski w Warszawie, Warszawa 2014.

24. Jencks Charles, Corbusier - tragizm współczesnej architektury, tłum. M. Biegańska, Wydawnictwa Artystyczne i Filmowe, Warszawa 1982.

25. Kaczmarczyk Jarosław, Czy modernizm może być atrakcyjny dla wspótczesnego turysty [w:] Modernizm w Europie. Modernizm w Gdyni, Architektura XX wieku do lat sześćdziesiątych i jej ochrona w Gdyni i w Europie, Urząd Miejski w Gdyni, Gdynia 2014.

26. Kaganiec Małgorzata, Tajemnice bytomskich kamienic, Towarzystwo Miłośników Bytomia, Bytom 1997.

27. Klajmon Barbara, Działalność architektoniczna Carla Bruggera na tle bytomskiej secesji, [w:] Oblicza secesji $w$ Katowicach $i$ na obszarze województwa Ślaskiego. Materiały z sesji Stowarzyszenia Historyków Sztuki, Oddziału Górnośląskiego w Katowicach 24 listopada 2005 roku, red. Dudek-Bujarek Teresa, Stowarzyszenie Historyków Sztuki. Oddział Górnośląski, Katowice 2006.

28. Koch Wilfried, Style w architekturze. Arcydzieła budownictwa europejskiego od antyku po czasy współczesne, tłum. W. Broniewski, R. Kunkel, Świat Książki, Warszawa 2005.

29. Kozina Irma, Chaos i uporządkowanie. Dylematy architektoniczne na przemysłowym Górnym Śląsku w latach 1763-1955, Uniwersytet Śląski w Katowicach, Katowice 2005.

30. Lewicki Jakub, Badania, definicje, wartościowanie a rzeczywistość, czyli dlaczego utracono czołowe dzieła polskiego modernizmu [w: Modernizm w Europie. Architektura XX wieku do lat sześćdziesiątych i jej ochrona $w$ Gdyni i w Europie, red. M.J. Sołtysik, R. Hirsch, Urząd Miejski w Gdyni, Gdynia 2014.

31. Marciniak Piotr, Niewygodny zabytek czy zła architektura? O kryteriach i sposobach ochrony powojennego dziedzictwa modernizmu [w:] Modernizm w Europie. Architektura XX wieku do lat sześćdziesiątych i jej ochrona w Gdyni i w Europie, red. M.J. Sołtysik, R. Hirsch, Urząd 
Miejski w Gdyni, Gdynia 2014.

32. Markgraf Monika, Budynek Bauhausu w Dessau. Poprawa efektywności energetycznej $z$ zachowaniem zasad konserwatorskich [w:] Modernizm w Europie. Architektura XX wieku do lat sześćdziesiątych i jej ochrona w Gdyni i w Europie, red. M.J. Sołtysik, R. Hirsch, Urząd Miejski w Gdyni, Gdynia 2014.

33. Olenderek Joanna, Gentryfikacja czyli degeneracja łódzkich dóbr kultury współczesnej z lat 60. XX w. [w:] Modernizm w Europie. Architektura XX wieku do lat sześćdziesiątych i jej ochrona w Gdyni i w Europie, red. M.J. Sołtysik, R. Hirsch, Urząd Miejski w Gdyni, Gdynia 2014.

34. Pietrusa Stanisław, Drzwi zewnętrze w starych kamienicach Szombierek i Bobrka, [w:] Z dziejów dzielnic Bytomia, red. Drabina J., Towarzystwo Miłośników Bytomia, Bytom 1991.

35. Sołtysik Maria Jolanta, Nowy wzorzec willi modernistycznej lat trzydziestych w Gdyni - willa z półokragła werandą. Powojenna kontynuacja idei [w:] Modernizm w Europie. Architektura XX wieku do lat sześćdziesiątych $i$ jej ochrona w Gdyni i w Europie, red. M. J. Sołtysik, R. Hirsch, Urząd Miejski w Gdyni, Gdynia 2014.

36. Szczypka-Gwiazda Barbara, Architektura i urbanistyka autonomicznego województwa ślaskiego w obrębie II rzeczypospolitej 1921-1939, [w:] Sztuka Górnego Ślaska od średniowiecza do końca XX w., red. E. Chojecka, Muzeum Śląskie, Katowice 2009.

37. Szczypka-Gwiazda Barbara, Urbanistyka i architektura ziem górnośląskich $w$ obrębie Republiki Weimarskiej 1918-1933 [w:] Sztuka Górnego Śląska od średniowiecza do końca XX w., red. E. Chojecka, Muzeum Śląskie, Katowice 2009.

38. Urbanik Jadwiga, Renowacja wzorcowego osiedla Werkbundu we Wrocławiu - sukcesy $i$ porażki [w:] Nowoczesność w architekturze. Warsztaty projektowe: Bytom - architektura pustych miejsc, Politechnika Śląska. Wydział Architektury, Gliwice 2007.

39. Witeczek Jerzy, Wstęp. [w:] Nowoczesność w architekturze. Warsztaty projektowe: Bytom architektura pustych miejsc, Politechnika Śląska. Wydział Architektury, Gliwice 2007.

40. Ustawa o ochronie zabytków i opiece nad zabytkami, Dz.U. 2014 poz. 1446, tekst jednolity z 10 września 2014, http://isap.sejm.gov.pl/DetailsServlet?id=WDU20140001446, [dostęp: 19.11.2015 r.]

41. Prawo budowlane, Dz.U. 1994 nr 89 poz. 414, ustawa z dnia 07 lipca 1994 r., http://isap.sejm.gov.pl/DetailsServlet?id=WDU19940890414. [dostęp: 19.11.2015 r.\} 